
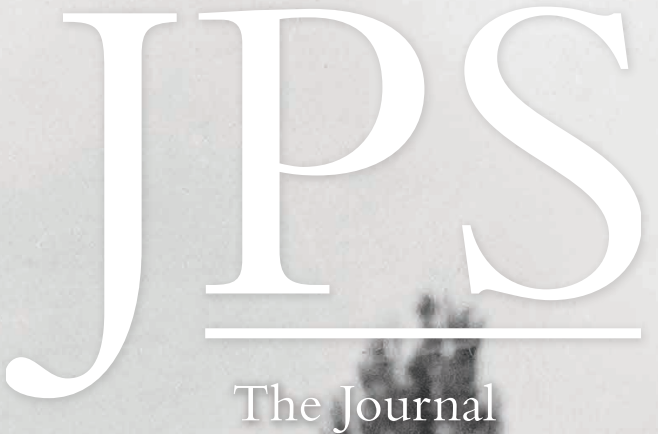

VOLUME 128 No.1 MARCH 2019

Special Issue

TE AO HOU: WHAKAPAPA AS

PRACTICAL ONTOLOGY

THE POLYNESIAN SOCIETY

THE UNIVERSITY OF AUCKLAND

NEW ZEALAND

of the

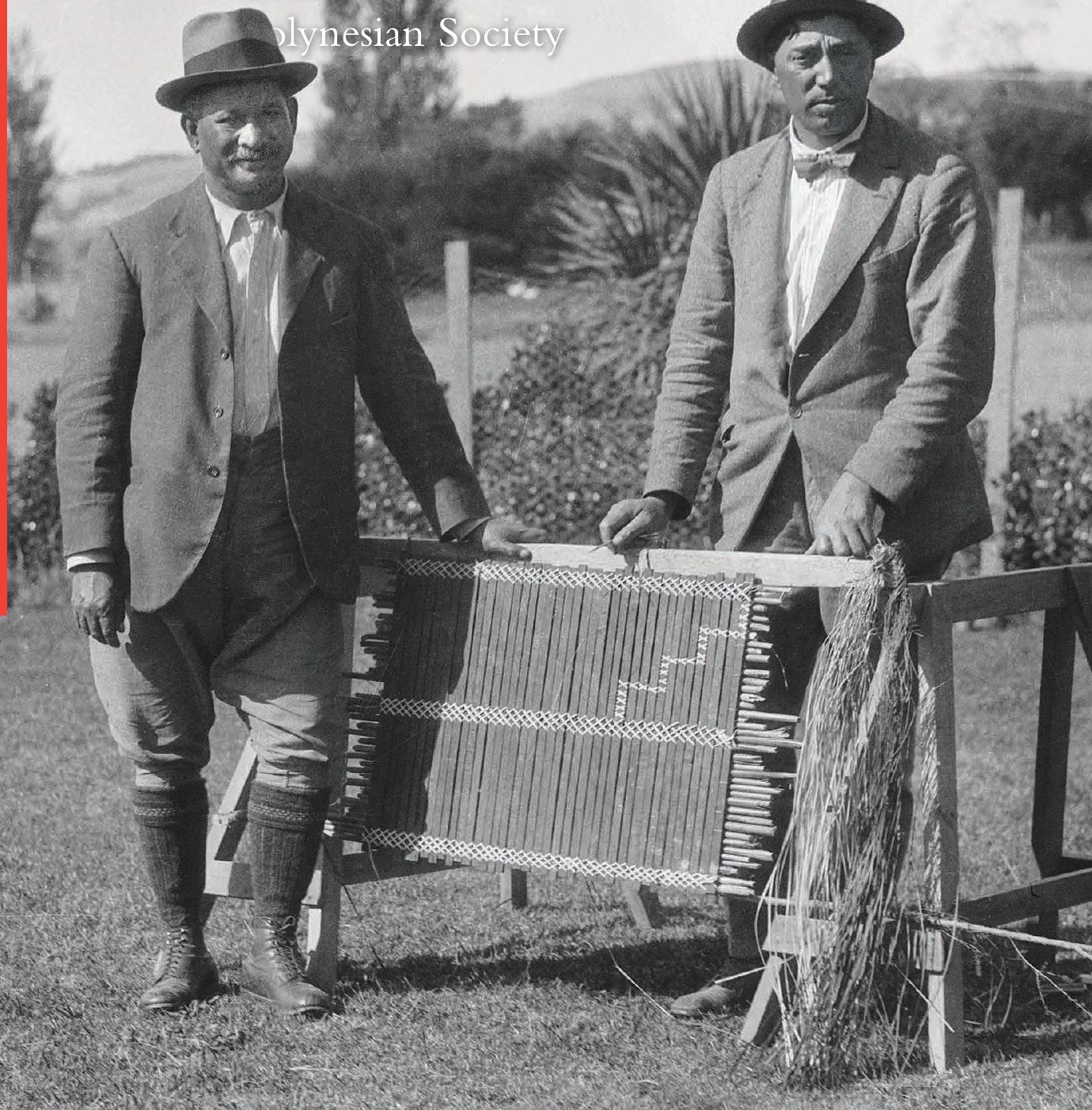




\title{
THE TERMINOLOGY OF WHAKAPAPA
}

\author{
APIRANA NGATA \\ Introduced by WAYNE NGATA \\ Aotearoa New Zealand Ministry of Education, Te Tāhuhu o te Mātauranga
}

\begin{abstract}
In the late 1920s and early 1930s Apirana Ngata wrote several texts based on his long-standing and extensive research into tribal genealogies or Māori whakapapa which, with the encouragement of Te Rangihīroa, were intended for a doctoral thesis on Māori social organisation. Although the doctorate was never completed, the fascinating fragments exploring the terminology of whakapapa brought together here, which survive in the Ngata family, the Alexander Turnbull Library and the Bishop Museum, stand as remarkable testament to indigenous scholarship in early twentieth-century Aotearoa New Zealand. In this rich and allusive text, Ngata explores the various material ways in which whakapapa is expressed in Māori language (te reo Māori), via meeting houses, weaving, twining and fishing techniques - a distinctively Māori view of kinship illustrating how whakapapa is employed as practical ontology, the subject of this Special Issue. In his Introduction, Wayne Ngata points out the value of this genealogical knowledge today and the ways in which it provides vital insights into traditional Māori ways of thinking and doing.
\end{abstract}

Keywords: whakapapa, genealogy, kinship, family, tribe, Ngāti Porou, knowledge, anthropology

\section{He kura ka huna \\ He kura ka whaakina \\ Treasured knowledge is hidden \\ And then it reveals itself}

Kia tīkina atu ngā kupu o te oriori a Ngāti Kahungunu hei wāhi ake i tēnei kaupapa, "Pinepine te kura, hau te kura, whanake te kura i raro i Awarua.

Ko te kura nui, ko te kura roa, ko te kura o tawhiti, nā Tūhaepō..."

Ko te kura i kōrerotia ai, e kōrerotia tonutia nei he āhuatanga whakaheke i ngā wānanga o Hawaiki mai, ka takitakina iho ki tēnei whenua kura e hora nei me ōna iwi. Kāti, he whenua, he whakapapa, he kōrero tonu e whakaorioritia ana hei oranga mokopuna, hei oranga tangata. Kei konei e āta whakaraupapahia ana e tō mātau tipuna, e Apirana, e tāea ai e tātau te whai kia mārama ai 
tātau ki a tātau anō, kia mōhio ai tātau me pēhea te whakatau, te whakarite, te whakaū i ngā tūhonohononga i waenganui i a tātau, e tika ai tā tātau noho ki te ao. Kia whakamihia ēnei tūāhuatanga i tukituki e ngā momo whakawai o te ao hou i ngā tau roa, kei moa te ngaro, me tiaki.

The relationship between Apirana Ngata and Te Rangihīroa (Sir Peter Buck) is materialised in many things, including the letters and manuscripts they exchanged. Keith Sorrenson published 174 of their letters in Na To Hoa Aroha, From Your Dear Friend: The Correspondence between Sir Apirana Ngata and Sir Peter Buck, 1925-50 (3 volumes). This paper publishes pieces of writing prepared by Ngata on the terminology associated with Māori genealogies, and sent to Te Rangihìroa during their long correspondence. This work, The Terminology of Whakapapa, has been lately uncovered in the archives of the Bishop Museum and the Alexander Turnbull Library.

Ngata had proposed to write a doctoral thesis on the "genealogical method". In a letter dated 11 January 1931, Ngata mentions to Buck that he is "dishing up the whakapapa matter alongside Nga Moteatea for the Litt. D" (Na To Hoa Aroha vol. 2: 226) and cites Te Kooro Kiriahuru as his mentor. Though the thesis was never submitted, the tracts below outline an extraordinary framework for understanding how whakapapa works. Ngata explores the various material ways in which whakapapa is expressed in te reo Mãori 'Maori language', via meeting houses, weaving, twining and fishing techniques - whakapapa as practical ontology.

Te Kooro Kiriahuru of the Tairāwhiti (East Coast of Aotearoa-New Zealand) was a noted genealogy expert of the late nineteenth and early twentieth centuries. He was consulted by Ngata and others in matters of genealogical knowledge and practice, and belonged to a class of tohunga 'experts' who were being, and have now been, overtaken by western models of absorbing, retaining and utilising bodies of knowledge. Te Kooro was what I would consider to be a "tribal database and software program" of insight, wisdom and practice as it pertained to connecting the complex networks of relationships between people through and across generations, that recognised, highlighted and reinforced obligations and responsibilities of those relationships. Modern genealogy software programs and apps have and continue to paint the relationship pictures we may desire, but have resulted in the loss of our ability and capacity to harness the incredible potential of our own human memory and understanding that traditional indigenous practice had maintained for many generations. We are fortunate that Ngata and others were able to record experiences and learnings they gathered in the company of the likes of Te Kooro. We have much to learn if we are to gain even the smallest of insights into our own traditional ways of thinking and doing. 
The manuscripts below were transcribed by Anne Salmond. The original texts did not include macrons and have been left as they were written. Notes in square brackets refer to missing pages or to insertions made by Ngata in black ink or by an editor in red ink, and highlight sentences that suggest that these manuscripts were written primarily for Te Rangihïroa's readership. ${ }^{1}$

Wayne Ngata

\title{
THE TERMINOLOGY OF WHAKAPAPA
}

\author{
APIRANA NGATA
}

[MS SC Buck 6.02, Bernice Pauahi Bishop Museum Archives]

In Maori various terms are used to define a pedigree or genealogy, or the act of tracing descent or setting out genealogically the relationship of persons or groups. A people such as the Maori, which had intense pride of race and a social system based largely on the family status of its members, would be expected to evolve a rich terminology relating to the preservation and transmission of pedigrees and the processes connected therewith.

\section{Recitation}

The only process by which pedigrees were communicated and transmitted, and thus taught and preserved, was by recitation, before the art of writing was acquired from the English.

The act of recitation was described by various terms according to the figure present in the mind of the reciter. If he conceived of the line of descent as a line, cord or string along which in imagination the persons concerned in the pedigree were strung in proper sequence he would use words appropriate to the act of tracing the particular string or cord. The words he would commonly use would be "taki" or "hapai." Those words would also be applicable to the idea of leading or lifting either a song or chant or story, and the reciter would become the fugleman in a massed haka or peruperu. A closely allied figure is expressed in the term "kauwhata." A kauwhata was a stage or frame built on which to suspend fish or bundles of food, which were tied together in such a way that the bundles straddled the cross-beams of the stage. There was a horizontal and a vertical method in the arrangement and display. It was no great step mentally to use a term which emphasised order, display and even decoration. This was the term "tatai."

In the term "tahu" or "tahuhu" (the former Eastern and the latter its equivalent among other tribes including Arawa, Tainui, Aotea and Ngapuhi) we have two conceptions, according as tahuhu is used as the first weft in the weaving of a garment, thus allied to "taki aho" or "hapai," or as the ridgepole of a house or as a stiffening rod. In the expression "tahuhu haere" the 
reciter is literally tracing this first weft, picking out the eldest son of the eldest branch of a family. The second conception of a ridge-pole and of the tribe or sub-tribe or family as a house with its connected parts is the one which is more usually present in the mind of the expert genealogist.

In the word "kauwhau" (also kauhau and kauhou) we have the basic idea of a tying together. "Whau" and "hou" are interchangeable as in whauwhau and houhou, and mean a tie; and "kau" is an ancestor. It seems to be at once the oldest and the most formal expression for ancient legends and genealogies and for the act of proclaiming them.

"Whakapapa" is the term in most common use. It introduces another conception, that of placing in layers or laying upon one another.

We shall develop all these terms and conceptions in detail.

(a) The line, string or cord.

Aho, kaha. Literally a line, string or cord. In relation to a pedigree or genealogy this is a figure that would naturally occur to a weaving, cordmaking, net-making, fishing people. The reciter conceived a connected string on which the persons concerned in the matter of his recitation were strung along in sequence and by lifting the string displayed them prominently. The string was the aho or kaha. The act of tracing it along in memory was "taki", and of lifting it "hapai".

Ex: From the song of Te Aratukutuku, who boasted of the people of Taupo: Hapainga te aho o to tupuna tama-wahine, i ariki ai ki te taniwha.

E kore e tau hei whai ake mo te taki aho ariki o te wahine maru kore.

Aho is most commonly used in the expression "aho ariki". Takiaho is a cord on which fish or shellfish are strung, and also a line of descent.

Kaha is a rope, rauawa lashings, a line or boundary, the navel string \&c., thence lineage or a line of descent, though in that connection now rarely used.

Ex: Ka hoki mai ki te whakataki i te kaha o Houmaitawhiti (T. 128)

"Taki" is to lead or bring along or to trace, and thus to recite in the days when recitation was the only method of tracing lines of descent, or history or traditions. We have it in taki tupuna, whakataki, takitaki and takiaho.

E taki ana i nga korero o mua

Ka takina te kawa.

Ka hoki mai ki te whakataki i te kaha o Houmaitawhiti, tae noa ki ana uri. 
E kore e tau hei whai ake mo te takiaho ariki.

Ka takitakina te haka,

Takitakina ra, e Horo, te hu o te puoro.

"Hapai" is to raise or lift up and in the line quoted from the song of Te Aratukutuku is applied to lifting or raising the aho ariki so as to display it. It is used in the same sense as "taki" for leading or raising the tune or tone of a song or chant.

In both taki and hapai you visualise the reciters one at each end of a line, now one now the other leading or taking the lead from the other as was the custom in the whare wananga.

"Whakaaraara" contains the same idea of lifting up or raising, and of chanting. As a noun it is a chant to keep the watch awake or give the alarm in time of war. (cf. Whakaaraara pa). As a term in relation to genealogies $\& c$. It means to recite or explain genealogies or other formal matter. The pedigrees or legends are visualised as a matua of component parts which experts in turn will arouse.

Ex: Ara atu ano pea etahi i mahue i a au, ma tetahi atu e whakaaraara atu. He nui nga mea kei waho atu i enei katoa i whakaaraaratia atu nei e au.

(b) The stage for display.

"Kauwhata" is to display as on a stage or frame in tied bundles, as of fish or articles of food, the elevation giving prominence. The figure is closely allied to that denoted by taki, hapai, aho and kaha.

Ex: E ora ana nga koromatua hai kauwhata i te riri (M. XCIX)

Te kauwhata o te atua

Ki te po wananga, ki te po kauwhata.

It is probably because in using these expressions, the reciter is seeking emphasis that we find them most commonly used in regard to ariki lines as in Takiaho ariki, kauwhata o te atua \&c.

(c) The first weft and (d) The ridge-pole or stiffening rod.

"Tahu or tahuhu". Reference has been made to the double conception denoted. We shall particularise here on the alternative figure of a ridge-pole or stiffening rod. 
In the cult of genealogies, "tahu or tahuhu" has a technical meaning. It is the act of setting out or arranging the main ancestors (connected with a common ancestor) from whom you may derive the tribe or tribes occupying a more or less extensive area. It has the idea of a horizontal arrangement with connected suspended lines that fits with both the conception of a weft and of a ridge-pole. Both weaving and house construction are so primitive that it is idle to speculate which complex derived the term from the other. The expert reciter was he who could most vividly impress on his hearers the array of related ancestors so that he might at will follow down any strand or rafter or poupou with the connected details of kaho, covering thatch or decorative tupuni. From any side or angle the suspended or propped up tahuhu challenged you to obscure it.

Te Kooro Kiriahuru, from whom I gathered enthusiasm for the cult of whakapapa, was master of the art of setting out "tahuhu" in whakapapa. It was amazing with what ease and sureness he would, after tracing out subsidiary lines in detail to the most recent date, revert to the tahuhu a little further along it to pick up connection with the next line, and so on.

In these days when recitation has given way to the written record the expert genealogist is he who can select from voluminous notes the "tahuhu" that will most clearly display the genealogical connections of all the hapu or whanau in a territory. The Arawa canoe landed in the Bay of Plenty a crew, whose orally transmitted genealogies show them to have been of one family in the Awarua on Rangiatea from which they migrated. And so we have-

Ko enei tangata, ko Tuamatua raua ko Uruika, ko raua te tahu nui o Te Hekengarangi, te tino kawai ariki, ko raua te tahu iho, tae iho ki nga uri.

On the East Coast lines you have to set out such names as Paikea, Uenuku, Ruawharo, Paoa, Whiro \&c. and connect them together either under Toi or the more distant Tawhaki, Wahieroa or Rata. After some generations in New Zealand these lines converge on Porourangi, Tahu, Ruapani, Rongowhakaata and Kahungunu; you thus get the local tahuhu.

And so in naming their superior houses after main or eponymous ancestors the tribes or tribe select their immediate ancestor from the tahuhu to form in turn the subsidiary tahuhu. The internal decorations, whether carved poupou or tukutuku panels may in turn follow down from the tahuhu commemorated in the name of the house or up to the main ancestor of the tribe, or you may as in Porourangi have both systems in operation.

In tahuhu you have the same conception as in aho kaha and kauwhata of something continuous, unbroken. 
(e) Orderly arrangement.

"Tatai" is to arrange or set in order, and as applied to genealogies is related to tahuhu. The idea of order or arrangement is emphasised and also of adornment. It may fit in very well as the Maori equivalent of the classical expression of adorning a tale. Hence "tatai korero" and "tatai tupuna" are particularly applicable to the orderly recitation of a line of ancestry or of the history of a people. Thence it was applied to the thing recited, especially the line of descent.

Ex: Kia ata tatai i te korero, kei pokapoka, engari kia tuhono noa atu. Ka tukua te tangata ki te tatai i nga kupenga a Marutuahu (Join the component parts of a fishing net).

Tatai kau ana te whetu i te rangi.

Ka mutu taua tatai wahine a Tangaroa.

(f) Tying together of ancient things. [corrected in red ink: "tieing"]

"Kauwhau, kauhau, or kauhou" is to recite, proclaim or declare aloud legends, genealogies or traditions. I have given what I consider to be the philology of the term and its literal meaning as to the tying together of ancestors or legends.

The kau of kaumatua and of the expressions "Na ona kau i waiho", "he korero huna na o kau" must be one of the roots; and hou, to tie, the other. If so then the basic idea is the same as in the expressions denoting a line or string or stage or weft or ridge-pole.

Ex: Kawhautia mai te kauwhau o te kino

I pu ai te riri, i mau ai te pakanga.

Whakaputa to reo ki te kauwhau riri.

A raua korero e kauhau nei mo Rangi raua ko Papa.

Whakaangi i runga i te kauwhau ariki.

(g) Layers.

"Whakapapa" is the term in most common use for the act of reciting a genealogy and for the genealogy itself. It introduces another conception in the reciter's mind.

Among the many meanings of the word "whakapapa" as a verb we may select as most relevant to our subject "to place in layers or lay upon one another'. Thus "whakapaparanga" is a layer or series of layers, and thus a 
generation or generations. Whakapapa is the act of reciting in proper order these layers or generations, whether the generation is composed of one individual as in the process called taotahi or tararere or of groups related along the one plane, as brothers, sisters of cousins to the nth degree and their wives and husbands.

Whakapapa opens up the widest scope of any of the terms used for the cult of genealogies. Where taki, hapai, kauwhata, tatai or tahuhu appear limited to special lines, kauwhau and whakapapa may comprise the most extensive relationships and involve the most complicated groupings.

Kauwhau probably had a wider vogue in former days, and is still the most formal expression, but whakapapa has almost ousted all other terms in these days, where its comprehensiveness covers much shallow knowledge and laxity.

Ex: Whakapapatia mai taua i to tipuna e korero na.

I haere mai ia ki te whakapapa i nga kauwhau o mua.

"Whakatakoto tupuna" is an expression related to whakapapa and with the same fundamental idea of laying down according to a plan. It is rarely used.

"Whakaparu" is a term that may be associated with whakapapa if as I believe it is derived from "paru", the thatching of bundles of raupo leaves. The association is in the idea of layering. I have not come across any example of the use of the term in regard to genealogies. Williams gives "whakaparu wahine" as descent through the female line only.

The reciter of legends and traditions, of tribal history and genealogies thus visualises his act in turn as tracing incidents or personnel strung along strings or cords or suspended on the cross-beams of hakari stages or from the first weft of a garment or from the ridgepole of a house or from any rod used to stiffen an object, or as uncovering the layers of stored information or of thatching. In kauwhau he has the figure of ancestors tied together by blood relationship. Pervading all is the idea of order, sequence and arrangement, and in boastful mood there is a suggestion of dressing and adornment, a lifting of pedigrees from out of the ruck.

It is doubtful whether he visualised a pedigree as a tree, with its head embedded by the hairy roots in Papatuanuku and trunk and branches vainly reaching up to Rangi above. Though the word "peka" is used for a branch of a family or tribe as in "Patua te peka kainga, ko te peka tangata kia ora" or "Ka whakarauoratia ko te peka tangata, ko te peka whenua ka whakamatea". I can find no example that would support the idea of a pedigree being likened to a tree. 
The fact that legends and genealogies could not be used, proclaimed or transmitted except by reciting them and that in practice this was done by groups of experts who passed the action to and fro drew into the terminology words associated with chanting and leading of tunes or chants.

\section{Methods in recitation}

\section{(a) Taotahi or Tararere}

If you pick up any family whakapapa book today, where the data was taken from the dictation of an elder towards the end of the eighth decade of last century it will reveal the following peculiarities:

1. It will give single names in each generation from the first ancestor recorded to the person then living, whose pedigree is the subject of the record.

2. If that person is also descended from a brother or sister of any ancestor after the first, the record will begin at the beginning and trace down to where the line will so descend.

3. When it happens that there is an intermarriage between ancestors in the divergent lines the reader is left to deduce the fact by noting that two ancestors traced on different pedigrees produce a child bearing the same name and having the same line descended from him.

The process of reciting genealogy in a single line of descent is called "taotahi" and among Ngati Porou "tararere". It was the process favoured by the multitude, most easily cultivated and acquired. It enabled you to sort up lines with aristocratic repute and so establish bowing connection with chiefs, whom you respect - fully classed as your tuakana or tamariki or mokopuna.

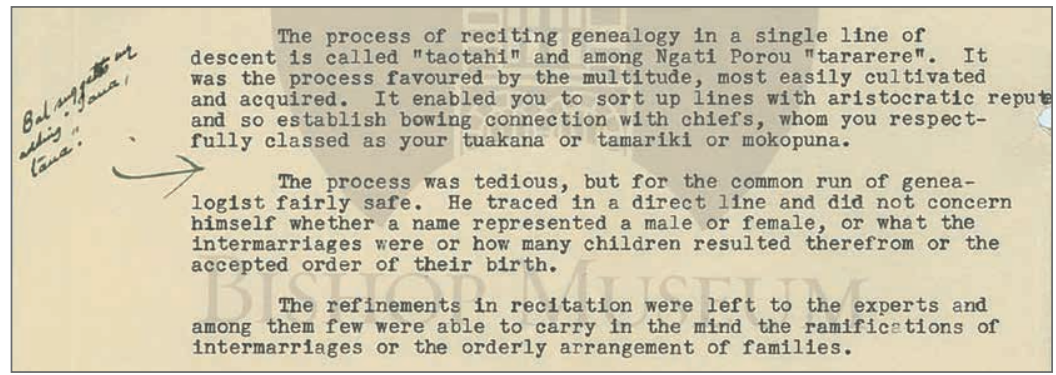

Figure 1. The note, in Ngata's hand-writing, reads, "Bal [Balneavis] suggests my adding 'Taua, taua'." 
The process was tedious, but for the common run of genealogist fairly safe. He traced in a direct line and did not concern himself whether a name represented a male or female, or what the intermarriages were or how many children resulted therefrom or the accepted order of their birth.

The refinements in recitation were left to the experts and among them few were able to carry in mind the ramifications of intermarriages or the orderly arrangement of families.

\section{(b) Whakamoe}

This was the act of tracing a genealogy assigning wives to males or husbands to females. It multiplied the strain on the memory and the margin of error more than two-fold. There was the risk of juxtaposing the wrong names by quoting as that of mate a name from the next generation, above or below, or placing in the direct line of descent the name of a wife or husband. For the Maori it must be remembered was, before writing was introduced, memorising by ear and had not the further aid of memorising by sight.

Nepia Pohuhu and others of the Wairarapa whare wananga experts may be quoted as deferring to Te Matorohanga in the matter of reciting intermarriages. And we may quote Te Matorohanga himself:-

"Kaore au e pai ki te taotahi i aku whakapapa; me ata whakamoe ano ka pai ai au."

\section{(c) Whakapiri}

This is the act of reciting parallel lines from a common ancestor in the taotahi style for each line so as to compare their length.

In planning a marriage "whakapiri" was used so as to keep the individuals concerned if possible on the same plane from a selected common ancestor, so that they would be tungaane and tuahine. If somebody called you by a relationship term, especially if it placed him a generation or so further than yourself from a common stock presumed to be in his mind, you would challenge him "Kei a wai?" so as to give yourself the opportunity by "whakapiri" of checking him.

\section{(d) Tahuhu}

This is the setting forth of Matri [inserted in red ink: main] sources of the lines of descent, those sources being connected with one another. Thus in regard to the progeny of a noted ancestor, especially the eponymous ancestor of a tribe, his various wives, if more than one, would be set out in proper order 
either of seniority if of one family or of related families or in order of the forming of the connections if known to tradition, and the children of each marriage, and sometimes the intermarriages of these and their descendants down to points, where the genealogist may indicate the branching off of a line or lines leading to the establishment and growth of new tribes or sub-tribes.

This is the highest art and comes nearest to the modern method of constructing genealogical tables.

(e) Hikohiko

In this process the reciter deliberately skips names on the vertical line down and sometimes interpolates names on the horizontal plane - the object being not so much to trace a continuous line as to indicate the relationship of the descendant sought to be distinguished, with the outstanding ancestors of various lines of descent. This is a common feature in poetry. Rangiuia's lament is a classic instance. In poetry too there is the factor of poetic licence in the selection of names that fit in with the lilt and metre of the song as well as its theme.

\section{(f) Ure tane and whakaparu wahine}

Tracing through male or female lines. The proudest descent was reputed to be in the eldest line through males. This was rarely achieved over many generations. Descent through males only irrespective of seniority, was termed "whakataki ure tane or ure tarewa." It is said that the late Mahuta Tawhiao and his full brothers, as also his son Te Rata and his brothers, have their ure tarewa or ure tane in their line of descent through Pikiao, an Arawa ancestor. The converse, descent through the female line only was termed "whakaparu wahine." And either may be an "ariki" line. Te Kani-a-Takirau boasted of a "whakaparu wahine" through "tapairu" or women of aristocratic lineage:

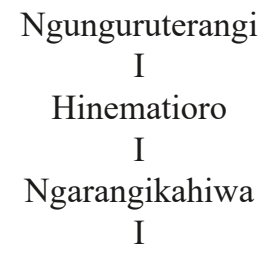

Te Kani-a-Takirau.

The tapairu were mated of course to consorts of the highest blood but not necessarily the eldest males, of the eldest branch of their respective families. 
Terms defining genealogy

We have given the terms used to define the act of recitation and the various methods used by the reciter.

Limiting the subject of recitation to cosmogonies, pedigrees or genealogies the various terms used for these may now be given.

We have given

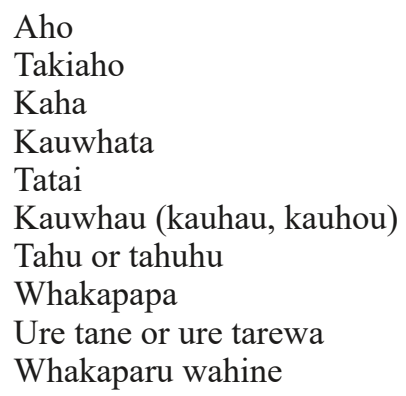

and indicated the ideas underlying them in the reciter's mind.

The list may be amplified thus:

Ara: ) Common expressions with the usual meaning.

Huarahi: )

Takina mai to huarahi i a Mahaki.

He ara tangata tonu no te kawai matua.

Kawai ) The figure is that of the shoot of a creeper or gourd, spreading from

Kawei ) the parent stem.

Takinga ou kawai, kia mohiotia ai ou tipuna.

Kaweka: Is allied to kawai, but suggests idling, rambling and digressing, therefore an indirect line of descent.

No te wa tauware, a stray shoot.

Hikahika matua: This is an unusual expression, and according to Williams is a direct line of descent. 
Terms for generation

We have given one- "whakapaparanga", a term derived from whakapapa meaning a layer and thus in relation to genealogies a generation.

Other terms are-

Ahunga: From "ahu" to foster, fashion:

Ata whaia ki tenei ahunga tangata.

Ko taua kuia no te ahunga i a kuoro.

Reanga: from "rea" to spring up, grow or multiply.

Whakatipuranga or whakatupuranga - from whakatupu, to cause to grow \&c.

Ko tenei korero mo te whakatupuranga o nga tupuna o te tangata Maori.

\section{Terms for groups of descendants}

These may be classified into (a) General terms for descendants (b) Terms for tribal or sub-tribal groups.

(a) Descendants are termed in a general way as uri, momo, aitanga, mokopuna, pori, whanau [inserted in black ink, in Ngata's hand: "and iwi may be added"']. An archaic form is ati, preserved for the most part in tribal appellations and words like mataati, and there are terms such as hoko, pu, waka, ngare, ure which fall properly into the next class. The word "whare" should perhaps be included in this class though its use in relation to descendants appears to be limited to the expression "whare ngaro", a line or family which has become extinct.

(b) Tribal appellations are an example of how archaic forms may linger on in names (whether of places, persons or objects). The archaic "ati" figures prominently as in Ati-Rua, Ati-Toa from Ngati-Rua, Ngati-Toa and is the usual form in Te Ati-awa. Nga-ati and Nga-ai are contracted to Ngati and Ngai to which the final element of some ancestral patronymic is added. Sometimes however this element is a word used to commemorate some incident viz: Ngati-Kumara, Ngati-Horomoana \&c. The difference in use between "ngai" and "ngati" appears to be one of euphony. The form "Ngai" is more frequent on the East Coast, whose dialect is prone to abbreviate or drop consonants. Thus Ngai-Tai at Torere is the name of the same tribe as the Ngati-Tai of the Western Hauraki Gulf. 
The Arawa and Tainui folk pay more punctilious attention to syllables containing consonants ahau-au, tonu-tou, mata-whaorua-matahourua \&c.

As tribal prefixes aitanga- (itanga), whanau, te ngare o, te ure o are in common use. It is remarked that these relate to the act of begetting and thus to those begotten. Ati in mataati, ati-a-toa, ika-i-te-ati relates to the young, the first procured or produced, the first fish, the young men in their first fight. Its use from time immemorial with tribal names suggests an original relationship with the act of procreation, unmistakeably preserved in the form Nga-ai \&c.

Te Ngare o- is a Tuwharetoa, probably a Tainui form, as Te Ure o- is distinctively Arawa. The other forms are universal but more common on the East Coast.

Te Whanau-a-Apanui
Te Whanau-a-Te Ehutu
Te Whanau-a-Maru
Te Whanau-a-Kaiaio
Te Whanau-a-Pararaki
Te Whanau-a-Tuwhakiriora
Te Whanau-a-Ruataupare
Te Whanau-a-Karuai
Te Whanau-a-Rakaihoea
Te Whanau-a-Tapuhi
Te Whanau-a-Hinetapora
Te Aitanga-a-Mate
Te Whanau-a-Rakairoa
Te Whanau-a-Te Haemata
Te Whanau-a-Iritekura
Te Aitanga-a-Hauiti
Te Aitanga-a-Mahaki
Ngai-Tai
Ngai-Tamanuhiri
Ngai-te-Rangi
Ngai-Tane.

The Ngati form is not frequent. We have Ngati-Porou, Ngati-Puai, NgatiHorowai (these two from drowning incidents as recently happened with the Whanau-a-Apanui of Maraenui who became Ngati-Horomoana), NgatiRangi, Ngati-Hau, Ngati-Konohi, Ngati-Rakaipaka, Ngati-Kahungunu. It may be observed however that Aitanga and Whanau were applied formerly to subsections of a main tribe, whether this had been named or not and gradually developed into groups worthy to be deemed tribes.

The use of "waka" and waka names for tribes should, I think, be regarded as a recent development. Our people had the Horouta canoe but never used that name as a territorial designation until the establishment of Maori Councils. 
Now it is not uncommon to hear some of the communities within the territory speak of themselves as Horouta - a use that may develop into the practice which has allowed Te Arawa to displace Ngaoho.

Lastly we have the word "hoko" associated with "ati" in the tribal namesTe hoko Ati-Rua, te hoko Ati-Puhi \&c. This Hoko is connected with hoko the prefix used with the numerals 1 to 9 to signify 20 times the subjoined numeral, and there is a multitude. Hoko Ati-is then the multitude of the Members of such and such a tribe.

I have a note of "pu" meaning a tribe. This is the "pu" of apu-a heap or collection, not the pu meaning origin, source.

(to be continued).

\section{THE TERMINOLOGY OF WHAKAPAPA (continued)}

APIRANA NGATA

[Ngata Papers, Micro MS 232, Folder 3/7, Alexander Turnbull Library; also in private collection of Dr Herewini Ngata.]

\section{Kinship terms}

The Maori kinship terms express both intimate or direct kinship, as true father or mother, or brother and sister, child and grandchild and collateral or indirect relationship. But it must not therefore be assumed that they did not in fact distinguish between near and distant kin. The vocabulary contains terms that separate the latter in definite fashion.

\section{Relatives}

The general term for relatives are "huanga" and "whanaunga", the latter prevailing among the East Coast tribes, where huanga is practically unheard of in the colloquial. A rare term is "pakanga". All terms denote blood relationship, descent from a common ancestor.

This common descent is called "puninga tahi", and relatives will claim, "he puninga tahi matou" (we come of a common ancestor).

Near relatives are called "tautau huanga" (the figure represented is that of a string or cluster of objects). "Pakanga kiritahi" is also used to describe near relatives, probably closer in through blood than the former term. Distant relatives are called "epeepe", literally small objects that are attached or cling to a main object, such as a rock. The distant relatives have parted so long or so far from the common stock that they have come cold or "mataotao", they "awhi" or merely embrace those who have remained close to the common ancestor.

The terms however do not convey distinctions as between lineal and collateral descendants. 


\section{Lineal and collateral descent}

The student must take care in seeking terms which may mark such a distinction to recognise that there may be a difference in conception between the Maori genealogist and the European sociologist, and that the former in defining relationships has a mental picture embracing on one canvas a much more extensive group than the latter. One stratifies mentally successive horizontal groups from a common stock and sees them lie equal distances from the common "pu", or "take" and therefore in the same relationship to one another along the common plane. His terminology thus tends to embrace all on that plane in relation to the common ancestor and to one another. The European sociologist on the other hand prefers what may be called the vertical view, and having selected a line, which for his argument he calls direct, distributes appropriate terms for the relationship of the individuals down that line. There are his terms to define kinship in the direct line, that is, linear descent. Those terms are used exclusively to define kinship in the direct line. As soon as you step to one side or the other of the direct line of descent the oblique relationships are described by other terms. Once a line is selected and called direct all others become indirect in relation to it, and all kinship of persons on those lines are deemed to be collateral in relation to persons on the selected direct line. His inherent individualism and his system of inheritance and succession to property engender not only preciseness in the terminology of kin but exclusiveness and rapid lopping off of receding relatives.

The Maori genealogist visualises vertical, horizontal, and oblique relationships as radiating from a common ancestor or a group of common ancestors. Perhaps it could be truer to picture his standing at a focus and defining the connection of all those round him whether above or below directly on either side of him or radiating to or from him as on a chart. Literally he is called upon to deal with a circle of relatives, all of whom appear intimate not only on his mental chart but in the everyday life of the area they inhabit. His traditional communal system, his system of inheritance, tracing on both the maternal and paternal side if both are connected with the ancestral stock whence rights and privileges or property is derived, the tendency of his race to embrace rather than exclude those related by blood conspire to make his terminology classificatory and apparently indiscriminating. It is not that he is not aware of the distinction between intimate and distant relationships, or that there is a basis of promiscuity which is best glossed over with terms of propriety. The Maori genealogist must in the nature of the case be precise and accurate. His social system demands that he should be polite and hospitable and the precise knowledge each family has of its detailed relationships is not sought to be overridden in any way by describing their connection with others outside themselves 
by the same terms they apply inter se. No one is deceived and the expert is the last person to attempt to deceive by the use of terms which translated into another tongue appear to exclude whole groups of individuals.

Here is a catechism. A father Anglice (sic) [Anglicised?] says to his son "Karangatia atu to papa ki te kai." The boy may ask "A wai?" and he might be told "A mea- hei tungaane hoki ki to koka." The child may by questioning learn that it is some cousin of his mother that is meant, but not a real brother. He will get at the relationship to himself of many relatives by this process, whereby he first eliminates all not in the direct line, tino or tuturu, possibly also those who are not first or second cousins and so forth. He will still be interested in many more more removed than the case of the European boy whose family circle is severely circumscribed by the social or economic system.

As the Maori lad grows up he perfects his education in the loose terminology used round him. He finds any amount of mentors to swell the data he must carry through life.

If then the Maori terms for lineal and collateral descendants confuse the European investigator they provide no pitfalls for those who grow up in it and whose education in the relationship of actual individuals to himself appear to be the care of all interested in him. It is our common experience in visiting the settlements to be confronted every hour and at every turn with short courses on relationships even from those who delight to rank you on the plane of their grandparents.

Maori kinship terms may therefore be said not to emphasise distinction between lineal and collateral descendants. But the distinction is there nevertheless and the terminology suggests its presence. Terms denoting relations which in the English relationship terminology are collateral kui (sic) [kin?] may be given as follows:-

Keke. In a different line: from "ke" different. So matua keke: uncle or aunt, matua meaning someone on the plane of a parent, male or female; tamaiti keke, nephew or niece.

There are no examples of the use of the terms for more distant relatives, such as cousins of the parents or children. Papa keke: Male relation in the same generation as father and mother.

Iramutu: Nephew or niece. The word tamaiti would embrace these, but if the precise relationship is to be emphasise the word is used.

Turanga whanau: Describes the relationship of cousins. It is used to limit the terms "tuakana", "taina", "tungaane", "tuahine" so as to remove all doubt whether these are intended to convey actual relationship through actual parents, direct kinship or something more distant. 
Terms denoting lineal descent

At this point it should be stated that the Maori terms which correspond to the English terms comprise relations excluded by the latter. Translation would merely confuse. Yet a statement in English must use terms that appear to correspond, and require explanation to show where they pass beyond the accepted meaning of the English terms.

We must for the occasion defer consideration of terms denoting relationship by marriage or adoption for these will only add to the confusion.

It is necessary to remember that we must tabulate our terminology for an individual on the direct line from a common ancestor and to define his relationship (1) to those in the direct line to or from himself and (2) to those who are in a different line from that ancestor, and (3) of any of those persons to himself.

The English terms are-

Grandparents; Grand-father, grandmother

Parents; father, mother

Children; son, daughter

Grandchildren; grandson, grand-daughter.

The individual whose relatives we are seeking to define by appropriate terms, let us say, the son on the English table.

The corresponding Maori terms may be considered in detail.

(a) Grand-parents.

The common term is "tupuna," tipuna among the East Coast tribes. (Our people experience difficulty with "tupu", "tupua", "tupuna", "tumu", "tumuaki", where the $u$ in tu is short. This is one of the dialectal distinctions. I explain it in the characteristics of the two main divisions of the North Island. That which we may roughly describe as Taihauauru (including the Arawa people) were more formal and deliberate in their language, especially the ceremonial or marae language. This is evidenced in the emphasis and value given to each syllable in a word. It was necessary even to interpolate a syllable like "nge" to make the mouthful. The Tairawhiti man was not so careful; his was a "reo mama", and he had a partiality for "au" instead of "ahau", "tou" for "tonu", and for the tripping "ti" instead of "tu".)

Whereas the English term is restricted to the actual grand-father and grandmother the Maori term is applied to their brothers or sisters or cousins to the 'nth degree or to any person in the same generation as either of them or in any earlier generation and related to them from a common ancestor. Tupuna is in fact the equivalent of the English "ancestor", including a grand-parent. [Manuscript ends here] 


\author{
RELATIONSHIP TERMS \\ [more extensive draft]
}

APIRANA NGATA

[Ngata Papers, also Micro MS 232, Folder 3/7, Alexander Turnbull Library]

\title{
1. Denoting lineal descent
}

a. Grandparent or ancestor

Tupuna is the common term and form except among East Coast tribes where it is "tipuna". (Our people experience difficulty with "tupu", "tupua", "tumu", "tumuaki", where the $\mathrm{u}$ is tu is short. This is one of the dialectical distinctions. I explain it in the characteristics of the two main divisions of the North Island. That which we may roughly describe as Taihauauru (including the Arawa people) were more formal and deliberate in their language, especially the ceremonial or marae language. This is evidenced in the emphasis and value given to every syllable like "nge" to make up the mouthful. The Tairawhiti man was not so careful; his was a "reo mama", and he had a partiality for "au" instead of "ahau," "tou" for "tonu", and for the tripping "ti" instead of "tu".)

Terms less commonly or rarely used beyond certain districts are:

Koroua: Arawa. This is also "Karaua", an old man

Poua

Taua

[Note. It is suggested that the roots "tua" and "ua" relate to the same thing - the back or backbone. Compare "Papatuanuku or Papa-tua-nuku.]

In this connection one might mention "katua"-full-grown, the adult of animals. With some tribes (I specify my own) it means the parent, more usually the mother. Also "matua". In "whakamatua" there is the idea of support or stiffening or mainstay. Matua and taua are connected in the military vocabulary and generally denote the main body of a war party. Our people would then in their lines of descent use primarily those words that stand for the "backbone", and no doubt is left that the relationship terms denoting lineal descent were first applied to direct descent and later extended for the reasons you mention in your letter to collaterals, eventually embracing tribal connections no matter how remote. [This sentence suggests that Apirana wrote this manuscript for Te Rangihïroa, rather than as a doctoral thesis per se.]

The Arawa use of "koroua" is significant, as that tribe attaches the utmost importance to the "ure tane" - the unbroken descent in the male line. The male ancestor would be uppermost in the mind of an Arawa genealogist 
whether on the marae or in the recitation of poetry. By the way the Tainui songs use the term freely.

"Kuia" is the sex equivalent of koroua, and is so used in poetry. But sometimes is used for "mother" especially when the woman is of advanced years. It is probably that it meant originally an "aged woman" and came to be applied to a mother of advanced age.

b. Parent.

The general term covering both sexes may be said to be "matua", especially in the plural, "mātua". I suspect though that originally "matua" was restricted in its application to the male parent, the father, and more often designates that today. With our people the male includes the female- the latter is an afterthought. Witness our table customs, the disinclination of the female to take her meal with the males - particularly the adult males of the family or at the same time. "Matua" and "whaea" are contrasted among the Tainui and other folk, as unconsciously as we should contrast "papa" and "koka" on the East Coast or "papa" and "kui" among Ngati Kahungunu.

"Papa" is perhaps a more intimate term than "matua". A mother would use it conversation with her child. On the other hand the use in later days by children of "Papa" or "E Papa" introduces the greater intimacy of the Anglicised Maori child. Williams says that the Arawa "papara" is used only of the true father. That may be so, but I suspect that an Arawa gave that limitation, as I have heard Arawas speak loosely of "papara" in the sense that "papa" embraces collateral, or in the [sentence ends here]

Equivalents for "papa" are:-

Koroua: Arawa, Tuwharetoa, Tainui. Among Ngapuhi means the collateral papa.

Kohake: Waikato. In Moteatea (Grey) 31 is the expression, "Kihai whakarangona te riri a te kohake". Ko is the root in "koeke", "kotiro", "koiwha", \&c. and heke is apparently the same as in "pahake" or Whanganui or Aotea peoples.

Matua: as above

Papara: as above

Whaea: As mother has a wider vogue that any other synonymous term-practically unknown on the East Coast until the early Maori catechists introduced it from the North, the Bible then broadcasting it with unfamiliar Ngapuhi terms. 
In "whaereere" however the root "whae" was familiarly known to East Coast folk-where "whaereere" is the most common term for "mother or child-bearing "wife" or the mother of one's children - an intimate term complimentary to the factor of child-bearing.

Whaene: A euphonious variant in vogue chiefly among you Aotea folk. [This again points to Te Rangihiroa as the recipient.]

The glottal closure must have induced termination by a consonant on which emphasis could be laid as against the open and inconclusive "a".

Hakui: The general N' Kahungunu term for mother apart from its broad application as an elderly or old woman.

Kui: In the N' Kahungunu district this is strictly applied only to a woman who is a mother. Apparently an abbreviation of "hakui."

Kuia: More often heard in the Arawa district in the same sense as "kui" or "hakui".

(Ku: would appear to be a root form. You have it in "kuao." Probably originated in the crooning of a child. With us " $\mathrm{E} \mathrm{ku}$ " is a term of endearment used by a mother to a loved baby and appears to [be] reciprocated by the child. "Kumama" is to desire or long for, used only of an invalid's fancy for certain foods.)

Karawa: Strictly "dam" of animals, but sometimes used as "mother" among a section of N' Kahungunu (Rakaipaka-Rongomaiwahine).

Koka: Is distinctively Ngati Porou and probably extended to Gisborne and the Whanau-a-Apanui in the same sense as "whaea".

Kokara: Williams says "Mother or true mother only"; Whaea is used more loosely. See my remarks on "papara." I have heard it only among Arawa.

Tia: A most unusual term, its use as mother or parent probably developed from "tia": the navel or abdomen.

Tiaka: Derived from "tia" and like "karawa" is strictly the dam of animals as opposed to "kuao" the young of animals, but often loosely applied as "mother" of human beings.

Ukaipo: Is poetical for "mother." Occurs frequently in East Coast songs-Williams quotes a Tologa Bay song "E hika, e ia, hoki mai ra ki au, ki te ukaipo o Tamakuhukuhu." 
In these intimate terms for the true mother or father two angles may be discerned:-

i. That of the child towards the parent emphasised in the case of the female parent by endearing terms such as "ukaipo", "hakui", "whaea", "koka".

ii. That of the third party commenting on the relationship "kohake", "tiaka", "karawa", "katua". Neither parent nor child would use these.

\section{c. Children.}

We should first deal with the terms denoting relationship towards the parents and not the relationship among children. The term of widest application is "tamaiti" (Pl. tamariki).

For the male child or son we may accept "tama". But (collaterals apart) it is not distinctive. It raises in the mind of the hearer the question that possibly the eldest child is meant. So that "tama" while defining relationship to the parents and the sex suggests also seniority among male children. And "tama" in the "whakatauki" may merely mean a "child" as in the example quoted by Williams "Kua whanau tama a Rangi" or in the better example, the Whanau-a-Apanui pepeha concerning Apanui-mutu, "Kua whanau tama a Rongomaihuatahi, he tane", "Rongomaihuatahi has borne a child, a son".

"Tamahine" for daughter is less liable to confusion than "tama." It does mean generally a daughter but in the proper context suggests the eldest daughter. In the plural there is no such liability to confusion. viz:-

By the way in your amended "Pakeha Pedigree" you make one mistake,

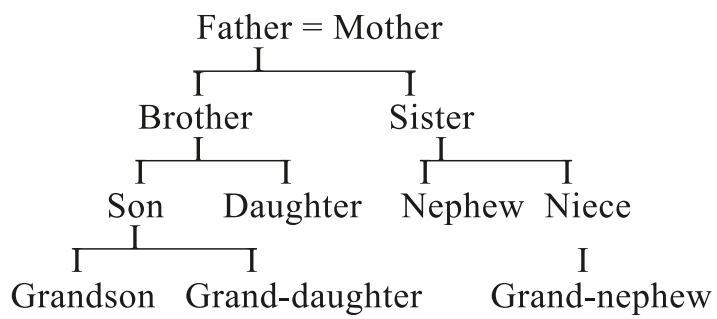

You have extended a generation too many. In tracing down the direct line of descent you must keep to the terms appropriate to the "tahuhu" or "aho", and use those which describe the relationship up or down and not as between individuals on the same plane. It is difficult to set it out in a table in such a way as to make the relationship terms completely relative. You can 
start out to describe the relationship between one generation and that which succeeds it and also the relationship of individuals on the same plane inter se. You would confuse parentage and childhood, with marital relationship or sex distinctions among children. You have only to add terms denoting order of birth (irrespective of sex) or seniority among children of either sex and you are in the soup.

\section{NOTE}

1. Editor's note: The structure and formatting of Ngata's original manuscripts are largely preserved in this published compilation.

\section{ACKNOWLEDGEMENTS}

The Bernice Pauahi Bishop Museum and the Alexander Turnbull Library gave permission for these manuscripts to be transcribed and published.

\section{REFERENCES CITED AND SOURCES}

Ngata, Apirana, ca. 1931. The Terminology of Whakapapa. MS SC Buck 6.02. Bernice Pauahi Bishop Museum, Honolulu.

n.d. The Terminology of Whakapapa (continued). Ngata Papers, Micro MS 232, Folder 3/7. Alexander Turnbull Library (ATL), Wellington. Originals in the possession of Dr Herewini Ngata, filmed at the ATL, 1979.

n.d. Relationship Terms. Ngata Papers, Micro MS 232, Folder 3/7. Alexander Turnbull Library, Wellington.

Sorrenson, Maurice Peter Keith (ed.), 1988. Na To Hoa Aroha: From Your Dear Friend. The Correspondence between Sir Apirana Ngata and Sir Peter Buck 1925-1950, vol. 1, 1925-29; vol. 2, 1930-32; vol. 3, 1932-1950. Auckland: Auckland University Press, Maori Purposes Fund Board.

\section{AUTHOR CONTACT DETAILS}

Wayne Ngata, 34 Monkhouse St., Tolaga Bay 4077, New Zealand.

Email: wjn@xtra.co.nz 
